\title{
Constraining the concentration of the hydroxyl radical in a stratocumulus-topped marine boundary layer from sea-to-air eddy covariance flux measurements of dimethylsulfide
}

\author{
M. Yang, B. W. Blomquist, and B. J. Huebert \\ Department of Oceanography, University of Hawaii, Honolulu, HI, USA \\ Received: 20 July 2009 - Published in Atmos. Chem. Phys. Discuss.: 30 July 2009 \\ Revised: 20 November 2009 - Accepted: 24 November 2009 - Published: 7 December 2009
}

\begin{abstract}
The hydroxyl radical $(\mathrm{OH})$ is an important oxidant in the troposphere due to its high reactivity and relative abundance. Measuring the concentration of $\mathrm{OH}$ in situ, however, is technically challenging. Here we present a simple method of estimating an OH-equivalent oxidant concentration ("effective $\mathrm{OH}$ ") in the marine boundary layer (MBL) from the mass balance of dimethylsulfide (DMS). We use shipboard eddy covariance measurements of the sea-to-air DMS flux from the Vamos Ocean-Cloud-Atmosphere-Land Study Regional Experiment (VOCALS-REx) in October and November of 2008. The persistent stratocumulus cloudcover off the west coast of South America and the associated strong inversion between MBL and the free troposphere (FT) greatly simplify the dynamics in this region and make our budget estimate possible. From the observed diurnal cycle in DMS concentration, the nighttime entrainment velocity at the inversion is estimated to be $4 \mathrm{~mm} \mathrm{~s}^{-1}$. We calculate $1.4( \pm 0.2) \times 10^{6} \mathrm{OH}$ molecules $\mathrm{cm}^{-3}$ from the DMS budget, which represents a monthly effective concentration and is well within the range of previous estimates. Furthermore, when linearly proportioned according to the intensity of solar flux, the resultant diel $\mathrm{OH}$ profile, together with DMS surface and entrainment fluxes, enables us to accurately replicate the observed diurnal cycle in DMS (correlation coefficient over $0.9)$. The nitrate radical $\left(\mathrm{NO}_{3}\right)$ is found to have little contribution to DMS oxidation during VOCALS-REx. An upper limit estimate of $1 \mathrm{pptv}$ of bromine oxide radical $(\mathrm{BrO})$ would account for $30 \%$ of DMS oxidation and lower the $\mathrm{OH}$ concentration to $1.0 \times 10^{6} \mathrm{OH}$ molecules $\mathrm{cm}^{-3}$. Our effective $\mathrm{OH}$ estimate includes the oxidation of DMS by such radicals.
\end{abstract}

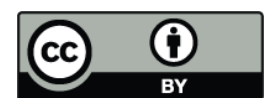

Correspondence to: B. J. Huebert (huebert@hawaii.edu)

\section{Introduction}

While non-reactive towards the major constituents of the atmosphere, the hydroxyl radical $(\mathrm{OH})$ is the principal oxidizing free radical in the troposphere for trace species (Levy, 1971). The primary source of $\mathrm{OH}$ is the reaction between water vapor and excited atomic oxygen $\left(\mathrm{O}\left({ }^{1} \mathrm{D}\right)\right)$; the latter is a product of the photo-dissociation of ozone $\left(\mathrm{O}_{3}\right)$ by photons between 290 and $320 \mathrm{~nm}$. Reduction of the hydroperoxy radical $\left(\mathrm{HO}_{2}\right)$ by nitrogen oxide $(\mathrm{NO})$, and to a lesser degree by $\mathrm{O}_{3}$, contributes to the recycling of $\mathrm{OH}$ (Donahue and Prinn, 1990). OH reacts readily with most trace gases and is often regenerated during the process, resulting in sustained $\mathrm{OH}$ concentrations on the order of $10^{6}$ molecules $\mathrm{cm}^{-3}$ globally (Prinn et al., 1995; Spivakowsky et al., 2000). The radical is consumed primarily by reacting with carbon monoxide (CO), but it also reacts with sulfur dioxide $\left(\mathrm{SO}_{2}\right)$, nitrogen dioxide $\left(\mathrm{NO}_{2}\right)$, and a wide range of hydrocarbons. Models predict higher $\mathrm{OH}$ concentrations for the tropics and for the Southern Hemisphere. The former is attributed to higher humidity and solar fluxes that promote $\mathrm{O}_{3}$ dissociation; the latter is presumably due to less $\mathrm{CO}$ south of the equator (a result of lower anthropogenic emissions; Seinfeld and Pandis, 2006).

Due to the transient nature of the radical, measuring $\mathrm{OH}$ in situ was not possible until the last two decades, when specialized instruments based on absorption, fluorescence, and mass spectroscopy were developed (e.g. Mount, 1992; Hard et al., 1984; Eisele and Tanner, 1991). However, direct observations of this radical cannot be made in all field experiments (such as during VOCALS-REx). Even when in situ OH measurements are available, they might not represent a temporal or regional average, which is of importance to large-scale models.

Published by Copernicus Publications on behalf of the European Geosciences Union. 
Alternatively, global and regional distributions of $\mathrm{OH}$ are often estimated by measuring chemicals with known lifetimes that are exclusively consumed by this radical, such as methyl chloroform (Prinn et al., 1992). Here we follow a similar approach and use a budget analysis of naturallyderived atmospheric dimethylsulfide (DMS) to constrain the equivalent $\mathrm{OH}$ concentration in a clean, stratocumuluscapped marine boundary layer.

Dimethylsulfide $\left(\mathrm{CH}_{3} \mathrm{SCH}_{3}\right)$ in the open ocean $\left(\mathrm{DMS}_{w}\right)$ is derived exclusively from phytoplankton. Due to photochemical destruction and rapid dilution, the atmospheric concentration of DMS is always orders of magnitude lower than the expected Henry's law equilibrium concentration with $\mathrm{DMS}_{w}$. Consequently, DMS gas always effluxes from the surface ocean and is the largest source of reduced sulfur to the atmosphere (Lovelock et al., 1972). The substantial magnitude of the flux and the lack of other sources make DMS an ideal gas with which to study air-sea exchange. In the atmosphere, DMS is principally oxidized by $\mathrm{OH}$ to form $\mathrm{SO}_{2}$, dimethylsulfoxide (DMSO) and methane sulfonic acid (MSA). $\mathrm{SO}_{2}$ may be oxidized further to form sulfate, which contributes to aerosol growth and formation of cloud condensation nuclei $(\mathrm{CCN})$. The coverage and lifetime of marine clouds formed from these $\mathrm{CCN}$ affect the earth's radiative balance and may in turn be linked to biological production in the ocean (Charlson et al., 1987; Kloster et al., 2006).

The oxidation of DMS by $\mathrm{OH}$ proceeds through two separate pathways: the hydrogen-atom abstraction at a methyl group that subsequently leads to mostly $\mathrm{SO}_{2}$ :

$\mathrm{CH}_{3} \mathrm{SCH}_{3}+\mathrm{OH} \cdot \stackrel{k 1}{\rightarrow} \mathrm{CH}_{3} S \mathrm{SCH}_{2} \cdot+\mathrm{H}_{2} \mathrm{O}$

and the $\mathrm{OH}$ addition to the sulfur atom that can lead to a wider range of products, including DMSO and MSA:

$\mathrm{CH}_{3} \mathrm{SCH}_{3}+\mathrm{OH} \cdot \stackrel{k 2}{\rightarrow} \mathrm{CH}_{3} \dot{\mathrm{S}}(\mathrm{OH}) \mathrm{CH}_{3}$

The abstraction pathway is favored under high temperatures; the Arrhenius form for this rate constant is $k_{1}=1.1 \times 10^{-11} \exp (-240 / T)$, equating to $4.9 \times 10^{-12} \mathrm{~cm}^{3} \mathrm{molec}^{-1} \mathrm{~s}^{-1}$ at $298 \mathrm{~K}$. The addition pathway is favored under low temperatures; this oxygen $\left(\mathrm{O}_{2}\right)$ and temperature dependent rate constant is best represented by $k_{2}=1.0 \times 10^{-39}\left[\mathrm{O}_{2}\right] \exp (5820 / T) /\left\{1+5.0 \times 10^{-30}\right.$ $\left.\left[\mathrm{O}_{2}\right] \exp (6280 / T)\right\}$ (Sander et al., 2006). At $298 \mathrm{~K}$, about $80 \%$ of the oxidation of DMS goes through the abstraction pathway; the two pathways are about equal at $285 \mathrm{~K}$ (Stickel et al., 1993; Wallington et al., 1993).

Other oxidants, including nitrate and halogen radicals, may also consume DMS. The nitrate radical $\left(\mathrm{NO}_{3}\right)$ is produced from the reaction between $\mathrm{NO}_{2}$ and $\mathrm{O}_{3}$. The DMS$\mathrm{NO}_{3}$ reaction is several times slower than the DMS-OH reaction. Unlike $\mathrm{OH}, \mathrm{NO}_{3}$ can only have an appreciable concentration at night because it is photolyzed rapidly during the day. Studies from Equatorial Christmas Island showed that in the remote Pacific, the contribution to DMS loss from
$\mathrm{NO}_{3}$ is less than a few percent due to the low levels of $\mathrm{NO}_{\mathrm{x}}$ $\left(\mathrm{NO}+\mathrm{NO}_{2}\right)$ away from anthropogenic activities (Davis et al., 1999; Chen et al., 2000). The same studies also suggested that the DMS-chlorine reaction, while still very poorly understood, accounts for no more than $5 \sim 10 \%$ to the oxidation of DMS. Other authors (e.g. Sciare et al., 2000) have found $\mathrm{OH}$ and $\mathrm{NO}_{3}$ to be inadequate in explaining their observed DMS losses, and speculated that the naturally derived bromine oxide $(\mathrm{BrO})$ might be another significant DMS oxidant.

The aforementioned Christmas Island experiments demonstrated a clear diurnal cycle of DMS in the MBL (Bandy et al., 1996; Davis et al., 1999). While the supply of DMS to the boundary layer via air-sea exchange is continuous, destruction of DMS principally takes place during the sunlit hours, when $\mathrm{OH}$ is available. As a result, DMS starts to increase from its daily minimum just before sunset and builds up through the night until just after sunrise, at which time photolysis causes DMS to decrease until the next cycle. This diurnal cycle in DMS can be altered in a pollution-influenced marine environment where anthropogenically produced $\mathrm{NO}_{\mathrm{x}}$ level is higher, as nighttime oxidation of DMS by $\mathrm{NO}_{3}$ can be comparable in magnitude to daytime oxidation by $\mathrm{OH}$ (Yvon et al., 1996).

The equivalent $\mathrm{OH}$ we estimate here from VOCALS-REx is an effective concentration, the concentration of $\mathrm{OH}$ that would cause the same rate of DMS loss as if $\mathrm{OH}$ were the only oxidant. In all likelihood, our effective $\mathrm{OH}$ is slightly higher than the actual $\mathrm{OH}$ concentration, since it includes minor contributions from the other oxidants.

The VOCALS-REx experiment took place in October and November of 2008 in the Southeast Pacific, off the west coast of Chile and Peru (http://www.eol.ucar.edu/projects/vocals/). The experiment aimed to address the interactions among the ocean, atmosphere, and clouds in this tightly coupled regional climate system. The Andes mountain range to the east forces strong winds parallel to the coast. Ekman transport results in coastal upwelling of cold, nutrient-rich waters, which leads to stability in the lower troposphere. The warm, dry air over the cool water surface, together with the largescale subsidence from the Hadley Cell, creates a widespread and persistent stratocumulus cloud deck (Bretherton et al., 2004). These thin, low-lying, and hence radiatively-cooling clouds form from $\mathrm{CCN}$ aerosols. While anthropogenic emissions dominate the coastal region, a significant fraction of CCN likely originates from DMS-derived sulfate in the clean marine environment offshore. From time to time, hundredkilometer sized openings (which can be observed from satellites) form in the stratocumulus cloud-deck and advect with the mean wind. These features have been coined "pockets of open cells" (POCs) and are hypothesized to be related to removal of CCN by drizzle from the air (Stevens et al., 2003). To further our understanding in this phenomenon, we need to look at the origin and fate of the $\mathrm{CCN}$-precursors, including DMS and its oxidants. 
A stratocumulus marine boundary layer is characterized by vigorous mixing due to the intense longwave radiative cooling at the cloud-top (Lilly, 1968). Air entrains down from the FT, which is balanced by a deepening of the MBL and wind divergence. The strong inversion in effect caps the MBL, confining surface-borne scalars like DMS. Therefore, a stratocumulus region such as the Southeast Pacific can be viewed as a natural analog to a box model, with clearly defined inputs and outputs. These simplified conditions enable us to estimate the effective $\mathrm{OH}$ concentration from mass balance.

\section{Experimental and methods}

The National Oceanographic and Atmospheric Administration (NOAA) ship Ronald H. Brown (RHB) was deployed in the Southeast Pacific from approximately 24 October to 30 November 2008. In addition to retrieving and maintaining the Woods Hole Oceanographic Institute's Stratus buoy at $85^{\circ} \mathrm{W}$ and $20^{\circ} \mathrm{S}$, a number of E-W transects were made at latitudes between $18.5^{\circ} \mathrm{S}$ and $21.5^{\circ} \mathrm{S}$ to survey eddies and upwelling features. The edges of such eddies are often associated with higher levels of biological productivity, hence more $\mathrm{DMS}_{w}$ (T. Bates and P. Matrai, unpublished data). In the same general time frame, multiple aircraft, including the National Science Foundation (NSF)/National Center for Atmospheric Research (NCAR) C-130, repeatedly flew westward from its base station in Arica, Chile to the stratocumulus region offshore. The anthropogenic influence was minimal away from the coast, with average $\mathrm{CO}, \mathrm{O}_{3}$, and $\mathrm{SO}_{2}$ concentrations of $65 \mathrm{ppbv}, 30 \mathrm{ppbv}$, and $25 \mathrm{pptv}$, respectively, typical of a clean MBL. Most of the research flights were designed to survey the $20^{\circ} \mathrm{S}$ cross-section and study the formation and development of POCs.

During the experiment, two nearly identical atmospheric pressure ionization mass spectrometers (APIMS) were used to measure DMS on board of $R H B$ and the C-130, the distinction being that the instrument at sea was sampling at a high rate of $20 \mathrm{~Hz}$ to quantify the sea-to-air flux, whereas the one aloft was measuring concentration every $10 \mathrm{~s}$. The measurement of DMS by the APIMS with isotopically labeled standard technique has been described previously (Bandy et al., 2002; Huebert et al., 2004; Blomquist et al., 2006). Most recently, Blomquist et al. (2009) discussed in great details about the instrument setup, flux processing, data refinement, and uncertainty estimates.

We estimate the $\mathrm{OH}$-equivalent oxidant concentration from the budget analysis of DMS. The conservation equation for any chemical species, $S$, in the marine boundary layer is represented in Eq. (3) (with the overbar representing an average in time/space):

$$
\frac{\partial \bar{S}}{\partial t}+\bar{u} \frac{\partial \bar{S}}{\partial x}+\frac{\partial \overline{S^{\prime} w^{\prime}}}{\partial z}=P-L
$$

The first term on the left represents the time rate of change in the concentration of $S$. The second term is the horizontal advection of $S$ due to gradients along the mean wind $(u)$. The third term is the flux divergence, the difference between vertical fluxes at the bottom and top of the box model. Local (chemical) production and loss of $S$ are represented by $P$ and $L$, respectively, on the right side of the conservation equation.

As described in the previous section, DMS fluxes upwards from the surface ocean to the stratocumulus-topped MBL, where it is oxidized (principally by $\mathrm{OH}$ ), diluted by DMSfree air entrained from the FT, and transported horizontally. DMS is not produced chemically, so $P=0$. Therefore the chemical loss due to oxidation can be calculated by closure if we know the DMS surface flux, entrainment flux, horizontal advection, and the time rate of change.

\subsection{Surface flux of DMS}

On the ship, the inlet of our mass spectrometer was located at $18 \mathrm{~m}$ above the water surface on the jackstaff, where flowdistortion due to the ship's superstructure is minimized. A precisely known amount of the triply-deuterated DMS standard was continuously injected at the inlet and combined with a high ambient air flow. The DMS concentration was determined from the ratio between the ambient and standard DMS mass spectrometer signals. Relative wind speeds, acceleration, and rotation in three axes were recorded at the same frequency as the DMS by a Gill Sonic anemometer and a Systron-Donner Motionpak accelerometer, respectively. Ship's motion was removed from relative winds to get true winds following Edson et al. (1998). To obtain surface flux $\left(F_{0}\right)$ via eddy covariance, DMS concentration was correlated with the vertical wind velocity $(w)$ in the form of $F_{0}=\overline{D M S^{\prime} w^{\prime}}$ (primes here denote deviations from the means). Flux was initially computed in ten-minute segments that overlapped by $50 \%$. To remove times when sampling conditions were unfavorable, any ten-minute segment with relative wind direction more than 90 degrees off the bow or gyro heading changing by over 10 degrees (ship maneuvering) was screened out. The remaining "good" segments were averaged to hourly values.

Time-series of 18-m DMS concentration and flux from the $R H B$ are shown in Fig. 1, with campaign means ( \pm standard deviations) of $57 \pm(26) \mathrm{pptv}$ and 3.4 $( \pm 1.9) \mu$ moles $\mathrm{m}^{-2} \mathrm{day}^{-1}$, respectively. Also shown are true wind speed and direction from the sonic anemometer at the same height. The wind direction hardly varied, almost always coming from the South/Southeast $\left(150^{\circ}\right)$. We limit our averaging to offshore observations only $\left(73^{\circ} \mathrm{W} \sim 86^{\circ} \mathrm{W}\right.$ and $18^{\circ} \mathrm{S} \sim 22^{\circ} \mathrm{S}$, hereinafter 'the VOCALS region'). Nearshore data were not included in the averaging due to anthropogenic influence as well as heterogeneities in the atmospheric DMS field caused by spikes in $\mathrm{DMS}_{w}$ on the edges of localized coastal eddies. 

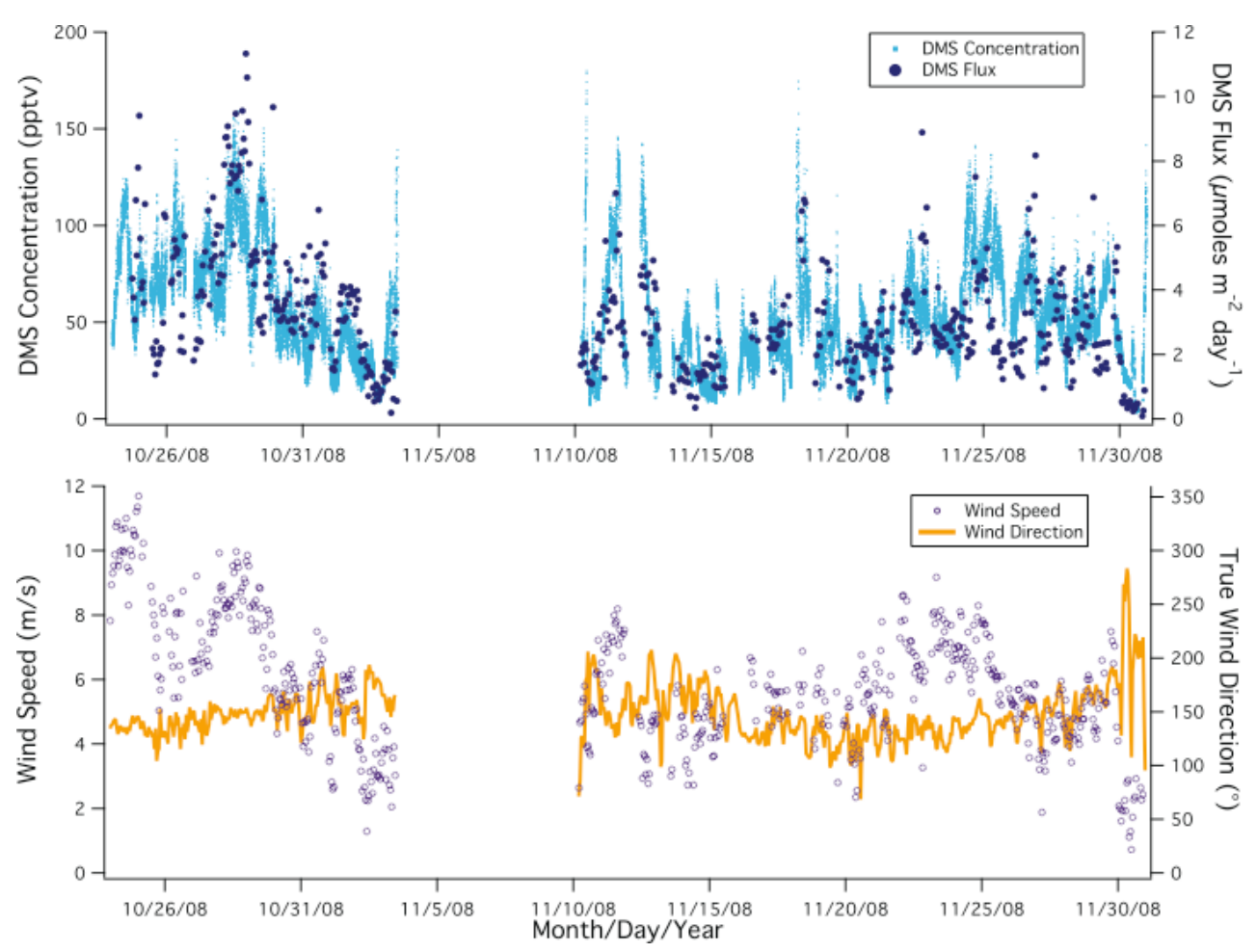

Fig. 1. Time-series of DMS concentration and surface flux (top), and true wind speed and direction (bottom) from the $R H B$ during VOCALSREx. Elevated DMS flux usually corresponded to spikes in $\mathrm{DMS}_{w}$ on the edges of localized eddies and high winds. The wind was consistently from the S/SE.

Even with the ship steaming at up to 12 knots, the classic sinusoidal diurnal cycle in DMS is clearly visible on a number of days (Fig. 2). This observation implies a widespread horizontal homogeneity over the region with limited mesoscale variability. Continental influence, which is usually associated with high levels of $\mathrm{NO}_{\mathrm{x}}$, and thus high $\mathrm{NO}_{3}$, was minimal.

\subsection{Boundary layer structure}

We determined the boundary layer structure during VOCALS-REx from shipboard radiosonde launches every six hours. Figure 3 shows a time series of temperature contours from the soundings, with the dark line indicating the inversion immediately above the stratocumulus cloud deck. Over the course of more than a month, the structure of the MBL was relatively constant, with an average temperature of $13^{\circ} \mathrm{C}$. In addition to radiosondes, a W-band radar $(24 \mathrm{~m}$ range gate, $50 \mathrm{~m}$ pulse length) from the ship measured cloud top height continuously. On average, the stratocumulus cloud top varied from $\sim 1350 \mathrm{~m}$ near dawn to $\sim 1200 \mathrm{~m}$ near dusk, suggesting a greater entrainment rate in the nighttime. Inversion heights determined from radiosondes are nearly identical with the cloud top estimates from the W-band radar (S. de Szoeke, personal communication, 2009).
We used DMS concentration from the C-130 aircraft $\left(\mathrm{DMS}_{C 130}\right)$ to infer the distribution of the scalar within the MBL and exchange with the FT. Figure 4 shows a typical profile of the lower troposphere during VOCALS-REx. DMS $_{C 130}$ decreased gradually with altitude within the MBL and rapidly dropped to near-zero above the stratocumulus cloud-top in the FT. Across the thin inversion layer of only a few tens of meters, the changes in dew point and potential temperature were usually of the order of 20 and $10 \mathrm{~K}$, respectively.

When the MBL is shallow and well mixed, scalars with long lifetimes are thought to be homogeneously distributed vertically. DMS in the boundary layer is emitted from the ocean surface and diluted by entrainment above; with a mixing time in the MBL $(\sim 1 \mathrm{~h})$ much shorter than its lifetime (1 2 days, estimated later), DMS concentration at the top of the MBL is usually only a few pptv lower than at the surface (Faloona et al., 2005). However, this difference was more significant in the VOCALS region, where the average inversion height was $1.3 \mathrm{~km}$. Figure 5 shows the mean profile from the $\mathrm{C}-130$ during the campaign. Altitude was normalized to the inversion height $\left(z_{i}\right)$. DMS $\mathrm{DM}_{C 130}$ aloft was normalized to the concentration from the lowest leg at $\sim 30 \mathrm{~m}$ $\left(\mathrm{DMS}_{C 130,0}\right)$. On average, $\mathrm{DMS}_{C 130}$ immediately below the inversion was $\sim 80 \%$ of the concentration near the surface, exhibiting a linear decrease with height. We linearly 


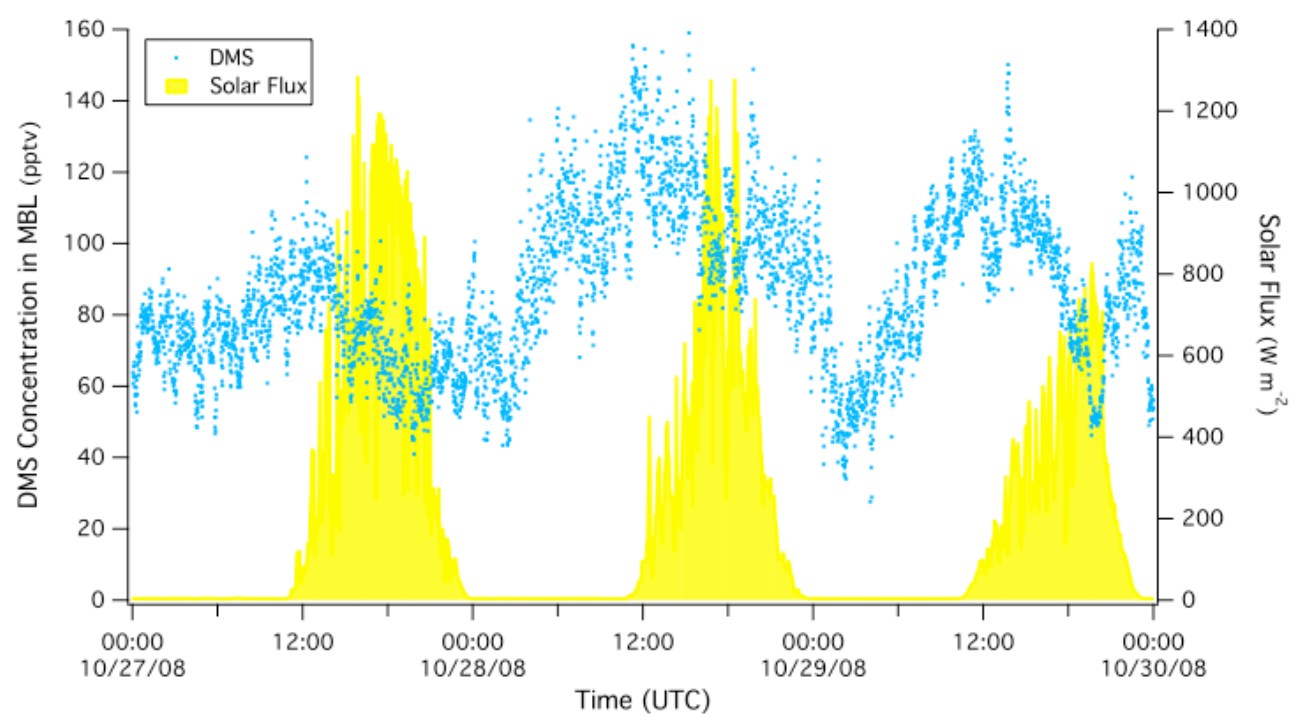

Fig. 2. Examples of diurnal cycles in DMS concentration observed from the RHB, along with solar flux measured from a shipboard radiometer. Maxima and minima in DMS were usually observed just after sunrise and just before sunset, respectively, as a result of continuous build up of the gas via air-sea exchange and daytime photochemistry.

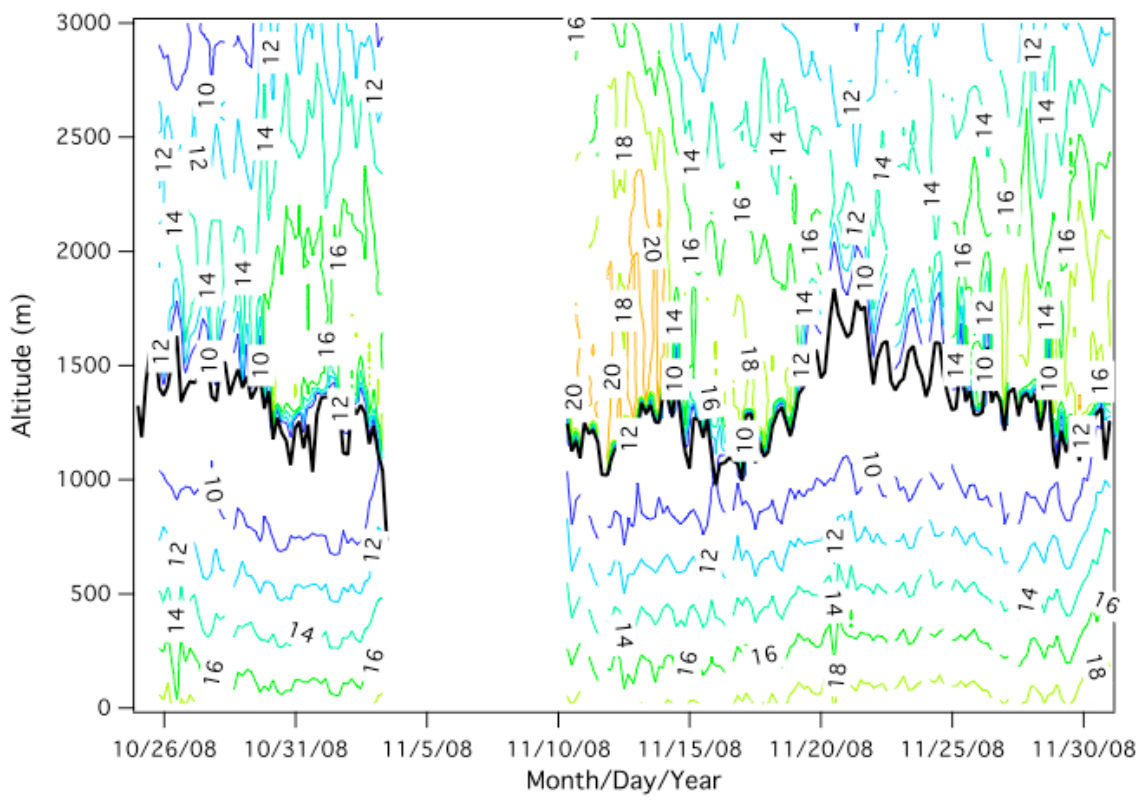

Fig. 3. Time-series of temperature contours from the radiosondes from the $R H B$, with the dark line indicating the inversion. Over a $\sim$ monthly timescale, the trend in the depth of the MBL along the E-W transect was relatively constant, deeper offshore (e.g. 26 October and 20 November) than near the coast (e.g. 3 and 10 November). The average temperature was $13^{\circ} \mathrm{C}$ in the middle of the MBL.

regressed $\mathrm{DMS}_{C 130} / \mathrm{DMS}_{C 130,0}$ against $z / z_{i}$ in the $\mathrm{MBL}$ $\left(r^{2}=0.8\right)$. The fraction of DMS at height $z$ relative to the surface value can then be parameterized as $1-\alpha\left(z / z_{i}\right)$, where $\alpha=0.2$ represents the "decoupling" parameter. This formulation of the MBL structure is similar to what is used in Wood and Bretherton (2004).

\subsection{Advective flux of DMS}

In VOCALS-REx, DMS concentration and flux measured from the ship show increasing trends away from the coast due to generally greater $\mathrm{DMS}_{w}$ concentration and higher wind speeds offshore (Fig. 6). The ratio between DMS flux and concentration, however, was nearly constant with longitude. Bin-averaged inversion heights from radiosondes and $18-\mathrm{m}$ 


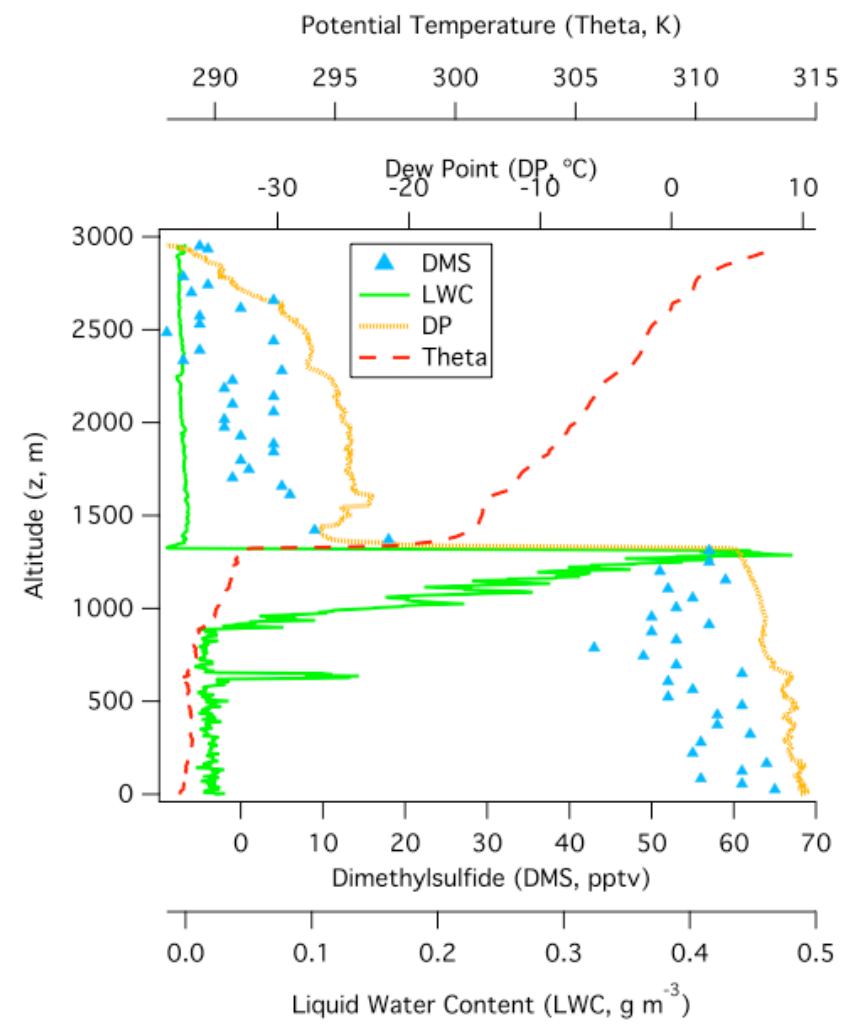

Fig. 4. A typical profile of the lower troposphere determined from the C-130 (12:24 12:35 UTC on Oct $25^{\text {th }}$ during Research Flight No. 5). DMS ${ }_{C 130}$ decreased linearly with altitude in the MBL (the lower $\sim 1300 \mathrm{~m}$ in this profile) and dropped to zero in the FT. A strong inversion atop the stratocumulus cloud deck (indicated by high liquid water content) was defined by sharp gradients in dew point and potential temperature.

wind speeds within the latitude range of $20 \pm 2^{\circ} \mathrm{S}$ are also plotted on the same figure. The boundary layer was deeper offshore $\left(\sim 1.5 \mathrm{~km}\right.$ at $\left.85^{\circ} \mathrm{W}\right)$ than at the coast $(\sim 1.1 \mathrm{~km})$, as is typical of this region.

We estimated the advective flux of DMS from the horizontal gradient computed from shipboard DMS concentration. Using multi-variate linear regression, DMS averaged to daily means (to remove diel variability) was regressed against Lat and Lon. The fitting coefficients were $-2 \mathrm{pptv}^{\circ} \mathrm{Lon}^{-1}$ and $-1 \mathrm{pptv}^{\circ} \mathrm{Lat}^{-1}$, with higher DMS towards the West/Southwest (Fig. 7). For an average wind speed of $6 \mathrm{~m} \mathrm{~s}^{-1}$ from $150^{\circ}$, multiplying the zonal and meridional winds ( -3 and $5 \mathrm{~m} \mathrm{~s}^{-1}$, respectively) by the DMS gradient gave an advection of $0.04 \mathrm{pptv} \mathrm{h}^{-1}$. Integrating over the $1.3 \mathrm{~km}$ column led to an advective flux of only $0.05 \mu$ moles $\mathrm{m}^{-2}$ day $^{-1}$, less than $1 \%$ of the DMS sea-to-air flux. Advection was small because the mean wind direction was largely orthogonal to the horizontal DMS gradient; we set it to zero hereafter.

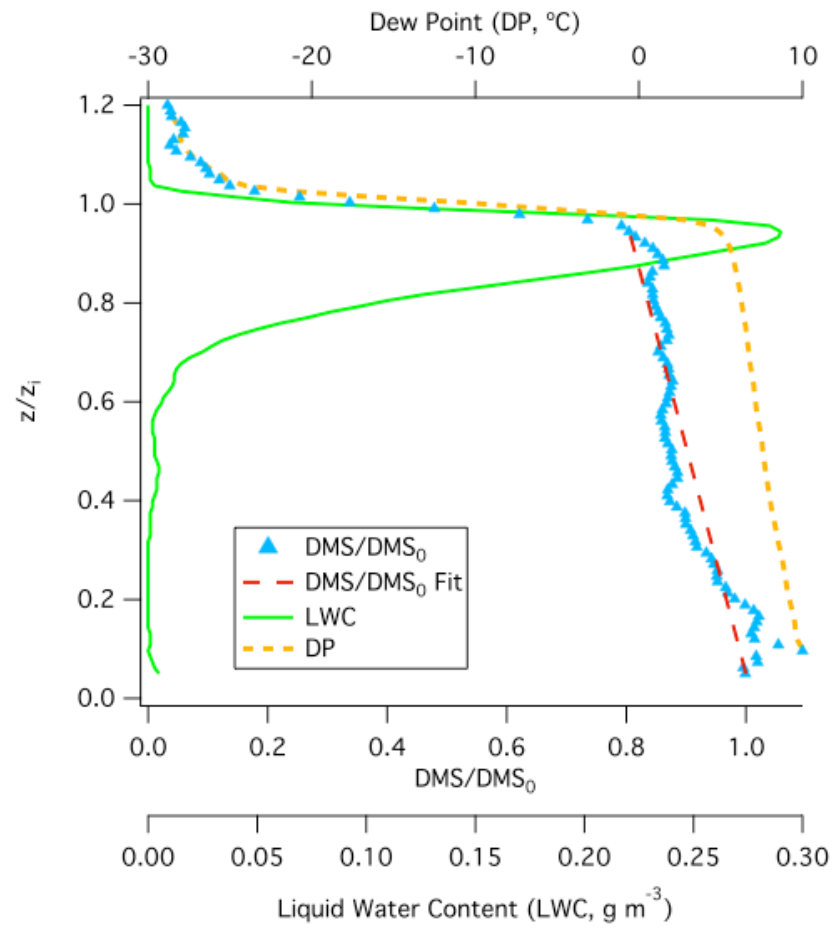

Fig. 5. Averaged profile from the C-130 with altitude normalized to the inversion height and $\mathrm{DMS}_{C 130}$ normalized to concentration from the lowest leg. Concentration at height $z$ is related to the nearsurface concentration by the parameterization $1-\alpha\left(z / z_{i}\right)$, with $\alpha$ being the DMS “decoupling" parameter and on average equaling to 0.2 .

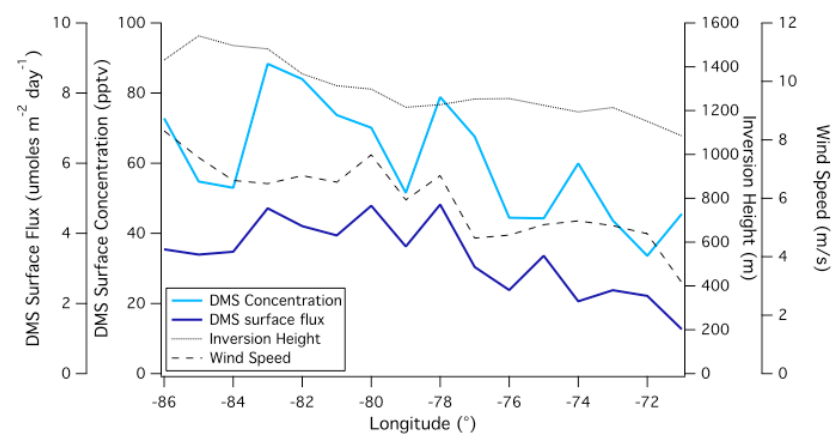

Fig. 6. VOCALS averages of atmospheric DMS concentration and surface flux from the $R H B$ in the latitude range of $20 \pm 2^{\circ} \mathrm{S}$, as well as wind speed and inversion height. The ratio between DMS flux to concentration was largely constant, suggesting minimal time rate of change in the DMS field on a monthly timescale. Both the boundary layer height and wind speed were greater offshore.

\subsection{Entrainment velocity}

To calculate the entrainment flux of DMS, we need to know the entrainment velocity $\left(\omega_{e}\right)$ at the inversion. While $\omega_{e}$ was not directly measured during VOCALS-REx, we can estimate it from the observed nighttime increase in shipboard 


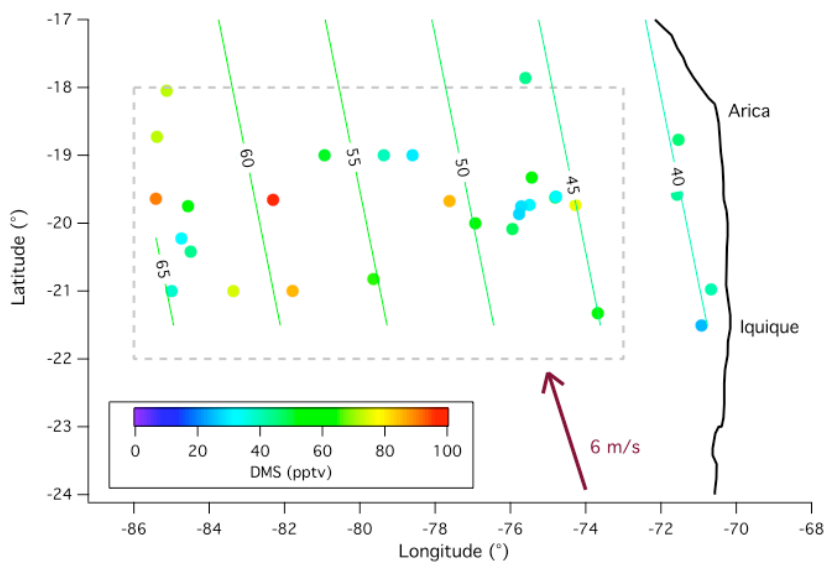

Fig. 7. Multi-regression of daily DMS concentration from the $R H B$ (colored circles) vs. Lat and Lon. Contours from the regression analysis show a gradient in DMS concentration that is orthogonal to the mean wind vector. The advective flux was thus minimal. The box with dashed lines defines the "VOCALS region."

DMS concentration. To account for the dilution effect from changing MBL depth, we integrate DMS concentration from the ship to the depth of MBL using the vertical gradient determined from Sect. 2.2, resulting in column concentration, $\langle\mathrm{DMS}\rangle$, in units of $\mu$ moles $\mathrm{m}^{-2}$.

The vertically integrated form of Eq. (3) is shown in Eq. (4), with the advection and production terms now dropped out. Now every term is in units of flux:

$$
\frac{\partial\langle\overline{\mathrm{DMS}}\rangle}{\partial t}=F_{0}-\omega_{e}\left(\mathrm{DMS}_{z_{i}^{-}}-\mathrm{DMS}_{z_{i}^{+}}\right)-k_{\mathrm{PFO}}\langle\overline{\mathrm{DMS}}\rangle
$$

The term on the left side of Eq. (4) is the time rate of change. The last term on the right represents the local loss of DMS, which has been expanded to the product of $k_{\mathrm{PFO}}$ (a pseudo first order reaction rate constant) and DMS column concentration. We have separated flux divergence into the first and second terms on the right hand side of Eq. (4), representing the DMS fluxes at the ocean surface and inversion, respectively. The entrainment flux is formulated as the entrainment velocity, $\omega_{e}$, multiplied by the concentration jump across the inversion (Lilly, 1968), with subscripts $z_{i}^{-}$and $z_{i}^{+}$ denoting just below and above $\mathrm{z}_{i}$. The concentration just below the inversion can be approximated from the $18-\mathrm{m}$ concentration by the fraction $(1-\alpha)$; the concentration above the inversion is taken to be zero. Equation (4) thus simplifies to:

$\frac{\partial\langle\overline{\mathrm{DMS}}\rangle}{\partial t}=F_{0}-\omega_{e}(1-\alpha) \mathrm{DMS}-k_{\mathrm{PFO}}\langle\overline{\mathrm{DMS}}\rangle$

The nighttime build up of DMS column concentration appears to be linear with time (Fig. 8). The slope over these hours approximately represents the time rate of change in $\langle$ DMS $\rangle$, which includes the flux divergence plus any nocturnal chemical loss. There is no $\mathrm{OH}$ at night, and we assume the $\mathrm{NO}_{3}$ reaction to be insignificant (this assumption

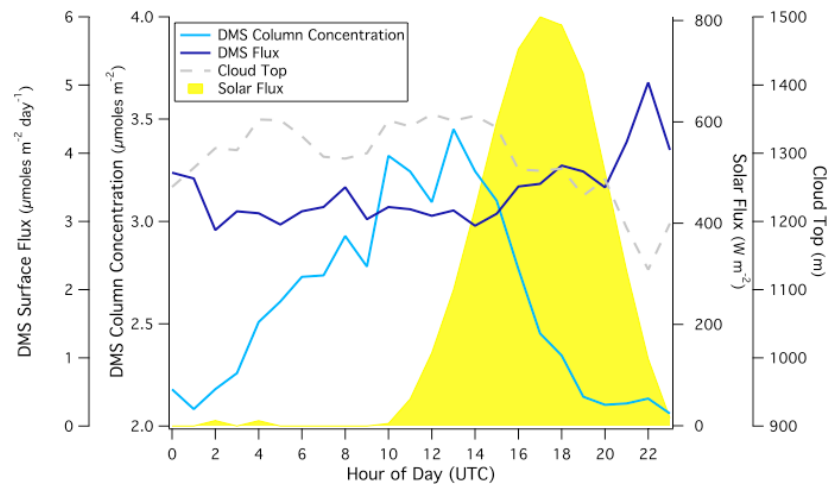

Fig. 8. DMS surface flux, column concentration, shortwave radiation, and cloud top measured from the RHB in the VOCALS region averaged to the time of day. The nighttime increase in DMS column concentration was approximately linear, enabling us to estimate an entrainment velocity of $4 \mathrm{~mm} \mathrm{~s}^{-1}$.

is validated in the last section); the loss term thus drops out. From hour 1 to 10:00 UTC (or 20:00 to 05:00 local time), we calculated a time rate of change in $\langle\mathrm{DMS}\rangle$ of $2.6 \mu$ moles $\mathrm{m}^{-2} \mathrm{day}^{-1}$. The mean nighttime surface flux obtained by eddy covariance was $3.2 \mu$ moles $\mathrm{m}^{-2}$ day $^{-1}$. The nighttime entrainment flux thus needs to be $0.6 \mu$ moles $\mathrm{m}^{-2}$ day $^{-1}$ to balance the budget, requiring $\omega_{e}=4 \mathrm{~mm} \mathrm{~s}^{-1}$.

The entrainment velocity derived above is only a nighttime value, and might not be representative of the climatological mean since there was possibly diurnal modulation of the inversion height. Shortwave heating of cloud top stabilizes the MBL and tends to reduce entrainment during the day, while longwave cooling at night may enhance entrainment. Off the coast of California, where stratocumulus clouds are also prevalent, eddy covariance flux measurements of three conserved scalars (DMS, $\mathrm{O}_{3}$, and total water) immediately above and below the inversion indicated a range of $1.2 \sim 7.2 \mathrm{~mm} \mathrm{sec}^{-1}$ for $\omega_{e}$, with higher values at night (Faloona et al., 2005). Using a mixed-layer approach, Caldwell et al. (2005) found a 6-day average $\omega_{e}$ of $4 \pm 1 \mathrm{~mm} \mathrm{~s}^{-1}$ during the East Pacific Investigation of Climate (EPIC) stratocumulus cruise in 2001. Combining satellite observations with National Centers for Environmental Prediction (NCEP) reanalysis, Wood and Bretherton (2004) determined an $\omega_{e}$ of $2 \sim 6 \mathrm{~mm} \mathrm{~s}^{-1}$ in the tropical and subtropical east Pacific, with a likely value of $4 \mathrm{~mm} \mathrm{~s}^{-1}$ in the VOCALS region. While our estimated nighttime $\omega_{e}$ could theoretically be an overestimate of the diurnal average, $4 \mathrm{~mm} \mathrm{~s}^{-1}$ appears to be a reasonable value compared to previous results. We show later that our calculated effective $\mathrm{OH}$ concentration is not very sensitive to the choice of $\omega_{e}$, because reaction with $\mathrm{OH}$ represents a far greater removal term for DMS than dilution due to entrainment. At the limit of zero for $\alpha$ (i.e. no decoupling in DMS), $\omega_{e}$ is lowered to $3 \mathrm{~mm} \mathrm{~s}^{-1}$, still within the range of previous estimates. 


\subsection{Estimating effective $\mathrm{OH}$}

From the clear diurnal cycles and near-constant flux to concentration ratio in the project averages (Figs. 2 and 6), diurnally averaged DMS field in the MBL appears to be approximately constant in space and time over the duration of the project. We thus assume DMS to be in a steady-state on that scale.

For the purpose of this derivation we first assume that the oxidation of DMS is solely due to reactions with $\mathrm{OH}$ (Eqs. 1 and 2). The pseudo first-order rate constant $k_{\mathrm{PFO}}$ in Eq. (5) is expressed as $k_{\mathrm{OH}}$, the total second order rate constant of the DMS-OH reaction $\left(k_{\mathrm{OH}}=k_{1}+k_{2}\right)$, multiplied by the concentration of $\mathrm{OH}$. With an average MBL temperature of $13^{\circ} \mathrm{C}$ during VOCALS-REx, we calculate $k_{O H}$ to be $7.9 \times 10^{-12} \mathrm{~cm}^{3}$ molec $^{-1} \mathrm{~s}^{-1}$, with the abstraction pathway accounting for $60 \%$ of the total oxidation.

Rearranging and expanding Eq. (5) with no time rate of change leads to:

$\mathrm{OH}=\frac{F_{0}-\omega_{e}(1-\alpha) \mathrm{DMS}}{\langle\overline{\mathrm{DMS}}\rangle k_{\mathrm{OH}}}$

Using $\omega_{e}=4 \mathrm{~mm} \mathrm{~s}^{-1}$ and $\alpha=0.2$, we find an effective $\mathrm{OH}$ concentration of $1.4 \times 10^{6}$ molec $\mathrm{cm}^{-3}$ for VOCALS-REx, somewhat higher than the estimated global average possibly due to high water content and solar radiation and low anthropogenic influence in this region. From PEM-Tropics A and B, which took place during September/October of 1996 and March/April of 1999, respectively, Olsen et al. (2001) showed that $\mathrm{OH}$ ranged from $1.4 \sim 1.8 \times 10^{6} \mathrm{molec} \mathrm{cm}^{-3}$ in the latitude range of $10 \mathrm{~S} \sim 30 \mathrm{~S}$ and in the lowest $2 \mathrm{~km}$, with higher values in the austral spring. The PEM-Tropics experiments did not extend into the stratocumulus region, however, where solar flux is lowered by $10 \sim 20 \%$ relative to the normal trade wind cumulus regime. An effective $\mathrm{OH}$ concentration of $1.4 \times 10^{6}$ molec $\mathrm{cm}^{-3}$ implies a lifetime of 1.1 days for DMS with respect to $\mathrm{OH}$ in the MBL, well within the range of previous estimates of $0.5 \sim 2$ days (e.g., Wine et al., 1981; Hynes et al., 1986).

Allowing for a substantial uncertainty of $\pm 2 \mathrm{~mm} \mathrm{~s}^{-1}$ in the entrainment velocity (due to diel variability, for example), the relative error in the calculated $\mathrm{OH}$ concentration is only $\sim 12 \%$ because dilution due to entrainment is small compared to photochemical loss. The potential of $\omega_{e}$ being biased high implies that our calculated $\mathrm{OH}$ might be an underestimate (though this could be partially compensated by the our assumption that $\mathrm{OH}$ is the only DMS oxidant). At a limit of $\alpha=0, \mathrm{OH}$ is lowered to $1.2 \times 10^{6} \mathrm{molec}^{-3}$. The uncertainties in the inversion heights from radiosoundes and the W-band were about $25 \mathrm{~m}$ (S. de Szoeke, personal communication, 2009). Assuming an absolute uncertainty of $2 \mathrm{~mm} \mathrm{~s}^{-1}$ for $\omega_{e}$ and 0.1 for $\alpha$, the propagated absolute uncertainty for the equivalent $\mathrm{OH}$ concentration is $\sim 0.2$ molecules $\mathrm{cm}^{-3}$, or $15 \%$. One apparent benefit of estimating $\mathrm{OH}$ from the DMS flux and concentration is that both measurements are made by the same instrument; any calibration uncertainty in the instrument (such as flow rate or standard concentration) is thus negated, not affecting the final outcome.

\section{Discussion}

The above $\mathrm{OH}$ estimate is an average value over a month. In reality, $\mathrm{OH}$ is only produced during the day when photochemistry is possible; the radical is consumed completely when there is no light. The next logical step is to approximate the diel variation in $\mathrm{OH}$, which has pronounced impacts on the cycling of sulfur species in the MBL, from DMS to $\mathrm{SO}_{2}$ to sulfate.

\subsection{Diel Variability in $\mathrm{OH}$}

To approximate the diel profile of $\mathrm{OH}$, we need to know the sources and sinks of the $\mathrm{HO}_{\mathrm{x}}\left(\mathrm{OH}+\mathrm{HO}_{2}\right)$ system because the $\mathrm{OH}: \mathrm{HO}_{2}$ ratio is usually a steady-state constant (Faloona et al. 2000). To a first order, the availability solar flux, and hence the ozone photolysis frequency, $J \mathrm{O}\left({ }^{1} \mathrm{D}\right)$, limits $\mathrm{OH}$ production since the subsequent reaction between $\mathrm{O}\left({ }^{1} \mathrm{D}\right)$ and water vapor is rapid. $\mathrm{OH}$ can also be recycled from $\mathrm{HO}_{2}$ by reaction with $\mathrm{NO}$ and $\mathrm{O}_{3}$. As for the sinks of $\mathrm{HO}_{\mathrm{x}}$, both the self-reaction of $\mathrm{HO}_{2}$ and $\mathrm{OH}+\mathrm{HO}_{2}$ (when $\mathrm{NO}_{\mathrm{x}}$ is low) represent quadratic loss in $\mathrm{HO}_{\mathrm{x}}$. In a high $\mathrm{NO}_{\mathrm{x}}$ environment, the $\mathrm{OH}+\mathrm{NO}_{2}$ reaction is the major sink and a linear loss for $\mathrm{HO}_{\mathrm{x}}$.

We can approximate the dependence of steady-state $\mathrm{OH}$ concentration on solar flux as $\mathrm{JO}\left({ }^{1} \mathrm{D}\right)^{b}$, with the exponent $b$ being $\mathrm{NO}_{\mathrm{x}}$-dependent. When $\mathrm{NO}_{\mathrm{x}}$ is high, $\mathrm{OH}$ relates linearly to $\mathrm{JO}\left({ }^{1} \mathrm{D}\right)$ because $\mathrm{HO}_{2}$ becomes less important (e.g. Holland et al., 1998). When $\mathrm{NO}_{\mathrm{x}}$ is low, $\mathrm{OH}$ is formed by the reaction with water vapor as well as from recycling of $\mathrm{HO}_{2}$ by $\mathrm{O}_{3}$ (and $\mathrm{NO}$, if any), while the loss of $\mathrm{HO}_{\mathrm{x}}$ is largely quadratic. Overall $b$ likely takes on a value between 0.5 and 1. Berresheim et al. (2003) found that $b=0.68$ off the coast of Crete in the Mediterranean, where the mean $\mathrm{NO}_{2}$ mixing ratio was $0.4 \mathrm{ppbv}$. While there was no direct measurements of $\mathrm{NO}_{\mathrm{x}}$ during VOCALS-REx, in situ observations from $10 \mathrm{~S} \sim 30 \mathrm{~S}$ during PEM-Tropics $\mathrm{A}$ and $\mathrm{B}$ yielded $5 \sim 10$ pptv of $\mathrm{NO}_{\mathrm{x}}$ in the lowest $2 \mathrm{~km}$ (Olson et al., 2001). Schultz et al. (1999) showed that in the tropical South Pacific, the median $\mathrm{NO}_{\mathrm{x}}$ level was only 4 pptv in the lowest $2 \mathrm{~km}$. Thus VOCALS likely falls in the low $\mathrm{NO}_{\mathrm{x}}$ regime and one may expect $b$ to be less than 1 .

We first binned solar flux measured by the shipboard radiometer in the VOCALS region to the time of day, which expectedly resulted in a smooth curve with peak insolation at $\sim$ 17:00 UTC. Not knowing the exact value of $b$, hourly hydroxyl concentrations $\left(\mathrm{OH}_{t}\right)$ were proportioned as linear and square root functions of the solar flux, with the diel average of the radical constrained by $1.4 \times 10^{6}$ molecules $\mathrm{cm}^{-3}$. The 

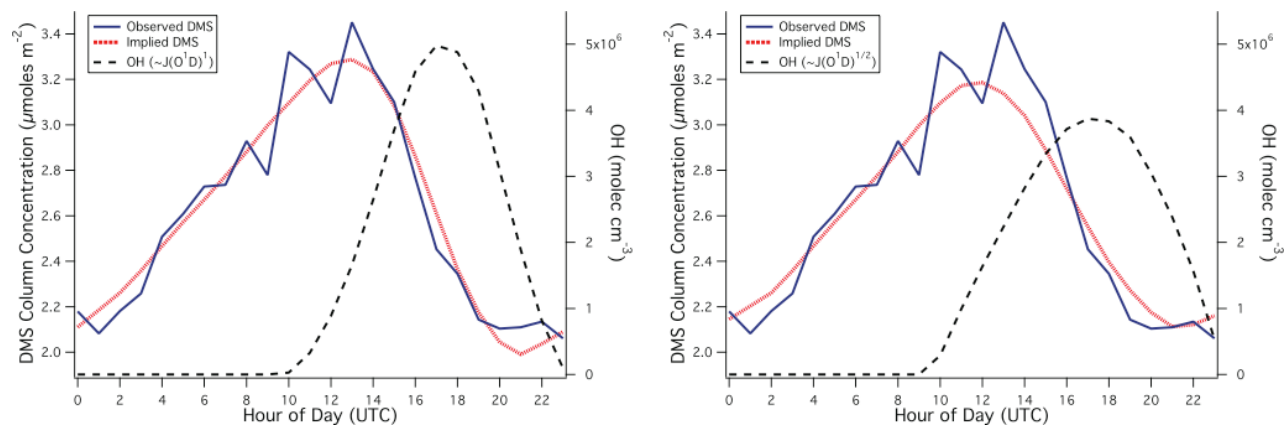

Fig. 9. Observed and implied DMS diurnal cycle: (a) with OH linearly proportional to the solar flux; (b) with OH proportional to the square root of the solar flux. A linear relationship between $\mathrm{OH}$ and solar flux yielded a better fit to the DMS diurnal cycle, despite the expected low $\mathrm{NO}_{\mathrm{x}}$ concentration. To investigate the importance of other oxidants, the $\mathrm{OH}$-equivalent oxidant concentration was apportioned to $\mathrm{OH}$, $\mathrm{NO}_{3}$ and BrO. Even a minuscule amount of $\mathrm{NO}_{3}$ was found to degrade the fit between the implied and observed DMS. BrO cannot be distinguished from $\mathrm{OH}$ based on the DMS diurnal cycle. For VOCALS-REx, the maximum DMS oxidation due to BrO was estimated to be $30 \%$.

radical peaked at $\sim 5 \times 10^{6}$ molecules $\mathrm{cm}^{-3}$ in the linear case and $\sim 4 \times 10^{6}$ molecules $\mathrm{cm}^{-3}$ in the square root case (with a broader distribution). While this method seems rather simplistic compared to photochemical models containing many photoactive species, the general shape of our derived diel $\mathrm{OH}$ profile agrees fairly well with previous direct observations in the tropical/subtropical Pacific basin (e.g. Davis et al., 2001; Mauldin et al., 2001). As another comparison to our effective $\mathrm{OH}$ estimate from DMS, we use photolysis rates of $\mathrm{O}_{3}$ and hydrogen peroxide $\left(\mathrm{H}_{2} \mathrm{O}_{2}\right)$ predicted from the NCAR Tropospheric Ultraviolet and Visible (TUV) Radiation Model (http://cprm.acd.ucar.edu/Models/TUV/), reaction rate between $\mathrm{O}_{3}$ and $\mathrm{HO}_{2}$, and destruction rate due to $\mathrm{CO}$, methane, hydrogen gas, $\mathrm{O}_{3}, \mathrm{H}_{2} \mathrm{O}_{2}$, and $\mathrm{HO}_{2}$ from Sander et al. (2006) to calculate the expected $\mathrm{OH}$ concentration. The TUV estimates photolysis rates based on time, latitude, longitude, and oxidant field, and accounts for clouds and aerosol scattering using climatological reflectivity from the Total Ozone Mapping Spectrometer (TOMS). The model yielded a noontime $\mathrm{OH}$ concentration of $\sim 6 \times 10^{6}$ molecules $\mathrm{cm}^{-3}$, which is $\sim 20 \%$ higher than our daytime peak in the linear scenario but likely within the range of uncertainties.

\subsection{Reproducing the diurnal cycle of DMS}

The oxidation of DMS in the atmosphere has been modeled previously given an estimate of OH (Shon et al., 2001; Nowak et al., 2001). Using a similar approach and building upon Eq. 5, the surface DMS concentration at time $t$ can be written as:

$\langle\overline{\mathrm{DMS}}\rangle_{t}=\langle\overline{\mathrm{DMS}}\rangle_{t-1}+F_{0, t-1}-\omega_{e}(1-\alpha) \mathrm{DMS}_{t-1}-$

$k_{\mathrm{PFO}, t-1}\langle\overline{\mathrm{DMS}}\rangle_{t-1}$

For simplicity, we used the average $\omega_{e}$ of $4 \mathrm{~mm} \mathrm{~s}^{-1}$, neglecting any potential diel variation in the entrainment veloc- ity. The implied DMS diurnal variation is not very sensitive to the choice of $\omega_{e}$ for the same reason as in Sect. 2.5.

We first equated, $k_{\mathrm{PFO}, t}$, the pseudo first order reaction rate constant of DMS, simply to $k_{\mathrm{OH}} \mathrm{OH}_{t}$, with $\mathrm{OH}_{t}$ being the time-dependent radical concentration calculated from Sect. 3.1. Figure 9a shows the diel cycle of $\mathrm{OH}$ approximated as a linear function of solar flux, DMS column concentration calculated from Eq. (7), as well as the observation. Figure 9b shows the same calculation except $\mathrm{OH}$ was approximated as a square root function of solar flux. It is apparent that the calculated DMS agrees closer with the observation when the dependence on solar flux, and hence $J \mathrm{O}\left({ }^{1} \mathrm{D}\right)$, is linear. In the square root case, implied DMS does not decrease as rapidly as observed after sunrise because the $\mathrm{OH}$ distribution is too broad. The linear dependence might come as a surprise given the expectedly low level of $\mathrm{NO}_{\mathrm{x}}$; this might be due to chemistry that are not considered or well understood. In the next section we explore the importance of nitrate and bromine oxide radicals in DMS oxidation, and see whether we can further improve the fit to the observed diurnal cycle.

\subsection{DMS Oxidation by $\mathrm{NO}_{3}$ and $\mathrm{BrO}$}

The rate constant of the DMS- $\mathrm{NO}_{3}$ reaction can be represented by $k_{\mathrm{NO}_{3}}=1.9 \times 10^{-13} \exp (500 / \mathrm{T})$, giving $1.0 \times 10^{-12} \mathrm{~cm}^{3}$ molec $^{-1} \mathrm{~s}^{-1}$ at $298 \mathrm{~K}$ (Sander et al., 2006). Studies from Allan et al. (2000) in the relatively clean MBL at Mace Head suggested that the nocturnal level of the nitrate radical hovers on the order of apptv, with reaction with DMS being its most important loss mechanism. Platt and Heintz (1994) estimated a globally averaged concentration of 3 pptv for $\mathrm{NO}_{3}$.

Uncertain about how much $\mathrm{NO}_{3}$ was present in the Southeast Pacific, we apportioned the total oxidative loss of DMS to fractions due to $\mathrm{NO}_{3}$ and $\mathrm{OH}^{\prime}$ (the prime denotes the "actual" $\mathrm{OH}$ concentration, assuming a linear dependence on 
solar flux). For example, if $10 \%$ of DMS oxidation was due to $\mathrm{NO}_{3}$, the ratio between diurnal averaged $k_{\mathrm{NO}_{3}} \mathrm{NO}_{3}$ and $k_{\mathrm{OH}} \mathrm{OH}^{\prime}$ should be 1:9. To crudely mimic the diel variation in $\mathrm{NO}_{3}$, we assume its nighttime level to be twice the diurnal average and the daytime concentration to be zero. In reality, $\mathrm{NO}_{3}$ might not achieve steady-state through out the night (Allan et al., 2000). We arrived at the closest least-square fit between observed and calculated DMS (correlation coefficient exceeding 0.9) when 99\% of DMS oxidation is due to $\mathrm{OH}$, as any additional $\mathrm{NO}_{3}$ would degrade the fit; this corresponds to less than 0.005 pptv of $\mathrm{NO}_{3}$. In all likelihood, low levels of $\mathrm{NO}_{\mathrm{x}}$ and $\mathrm{O}_{3}$ were limiting the production of $\mathrm{NO}_{3}$ during VOCALS-REx.

The rate constant of the DMS-BrO reaction can be represented by $k_{\mathrm{BrO}}=1.4 \times 10^{-14} \exp (950 / \mathrm{T})$, yielding $3.4 \times 10^{-13} \mathrm{~cm}^{3} \mathrm{molec}^{-1} \mathrm{~s}^{-1}$ at $298 \mathrm{~K}$ (Sander et al., 2006). Read et al. (2008) measured BrO with differential optical absorption spectroscopy (DOAS) at Cape Verde in the tropical Atlantic Ocean. They found an average $\mathrm{BrO}$ concentration over 2 pptv during the day and zero at night, with a diurnal profile resembling a "top hat" distribution.

During VOCALS-REx, with a similar DOAS technique, no significant $\mathrm{BrO}$ was detected, with $\sim 1$ pptv being the upper limit daytime peak concentration (R. Volkamer, personal communication, 2009). The same instrument also detected $\sim 1$ pptv of iodine oxide (IO), a level insignificant towards DMS oxidation due to its much lower reactivity. If we crudely approximate the diurnal profile of $\mathrm{BrO}$ with a square root dependence on solar flux, 1 pptv of daytime maximum $\mathrm{BrO}$ implies a diel average concentration just under $0.4 \mathrm{pptv}$. This upper limit concentration of $\mathrm{BrO}$ would account for $\sim 30 \%$ of total DMS oxidation; the $\mathrm{OH}$ concentration would then need to be reduced to $1.0 \times 10^{6}$ molecules $\mathrm{cm}^{-3}$. The shape of implied DMS from Eq. (7) with this allocation of oxidants is not significantly different from what is shown in Fig. 9a. Therefore from the implied DMS diurnal cycle alone, it is difficult to assess whether $1 \mathrm{pptv}$ of $\mathrm{BrO}$ is too high. Our $\mathrm{OH}$-equivalent oxidant concentration may still include other DMS oxidants, such as $\mathrm{NO}_{3}$ and $\mathrm{BrO}$.

\section{Conclusion}

We have demonstrated that a month-long average $\mathrm{OH}-$ equivalent oxidant concentration in a stratocumulus-capped marine boundary layer can be derived from the sea-to-air flux and concentration of DMS measured from a ship with a simple mass balance method. From aircraft profiles during VOCALS-REx, DMS concentration appeared to decrease linearly with altitude in the MBL due to decoupling. On average, DMS immediately below the inversion was $\sim 80 \%$ of the surface concentration. DMS concentration in the MBL displayed the classic sinusoidal diurnal cycle, in which daily maxima and minima were found to be just after sunrise and just before sunset, respectively, as a result of the continu- ous build up via air-sea exchange and daytime consumption by photochemistry. From the nighttime build up of DMS column concentration, we estimated an entrainment velocity of $4 \mathrm{~mm} \mathrm{~s}^{-1}$ from the difference between the time rate of change and the observed surface flux. The advective flux of DMS was found to be insignificant because the horizontal gradient in DMS was largely perpendicular to the mean wind direction. The calculated $\mathrm{OH}$ concentration of 1.4 $( \pm 0.2) \times 10^{6}$ molecules $\mathrm{cm}^{-3}$ from the DMS budget equation agrees well with previous estimates, and represents a regional $\mathrm{OH}$-equivalent oxidant concentration. Actual $\mathrm{OH}$ will be less by the extent that other DMS oxidants, such as nitrateand halogen- radicals, react with DMS. The applicability of this approach of estimating the equivalent-OH concentration hinged on the stationarity and horizontal homogeneity of the region over a long enough time scale. Areas with much greater mesoscale variability or additional source and sink terms will complicate the budget analysis.

We fitted the $\mathrm{OH}$-equivalent oxidant concentration as both linear and square root functions of the observed solar flux averaged to the time of day. Using the resultant diel profiles in $\mathrm{OH}$, the mean observed DMS surface flux, and an entrainment velocity of $4 \mathrm{~mm} \mathrm{~s}^{-1}$, we were able to accurately replicate the observed diurnal cycle of DMS in the MBL. Despite the expected low $\mathrm{NO}_{\mathrm{x}}$ concentration, a linear relationship between $\mathrm{OH}$ and solar flux, and hence $J \mathrm{O}\left({ }^{1} \mathrm{D}\right)$, yielded a better fit between observed and implied diurnal cycles (correlation coefficient over 0.9) than a square root relationship. The nitrate radical was considered in the DMS oxidation and found to be unimportant in VOCALS-REx. We cannot rule out $\mathrm{BrO}$ as a possible oxidant, however. An upper limit estimate of $1 \mathrm{pptv}$ of $\mathrm{BrO}$ (daytime peak) would account for $30 \%$ of total DMS oxidation, lowering our effective $\mathrm{OH}$ to $1.0 \times 10^{6}$ molecules $\mathrm{cm}^{-3}$.

Acknowledgements. We thank the National Science Foundation for support of this work through grant ATM-0241611 and ATM0526341. Aircraft thermodynamic data and gas concentrations were provided by NCAR/EOL under sponsorship of the NSF. Aircraft DMS data was provided by Drexel University. Special thanks to C. W. Fairall, NOAA, S. de Szoeke, Oregon State University, R. Volkamer, University of Colorado at Boulder, S. Conley, University of California, Davis, R. M. Simpson, University of Hawaii at Manoa, and the crew of the $R / V$ Ronald H. Brown.

Edited by: L. Carpenter

\section{References}

Bandy, A. R., Thornton, D. C., Blomquist, B. W., Chen, S., Wade, T. P., Ianni, J. C., Mitchell, G. M., and Nadler, W.: Chemistry of dimethylsulfide in the equatorial Pacific atmosphere, Geophys. Res. Lett., 23(7), 741-744, 1996.

Bandy, A. R., Thornton, D. C., Tu, F. H., Blomquist, B. W., Nadler, W., Mitchell, G. M., and Lenchow, D. H.: Determination of the vertical flux of dimethylsulfide by eddy correlation and atmo- 
spheric pressure ionization mass spectrometry (APIMS), J. Geophys. Res., 107(D24), 4743, doi:10.1029/2002JD002472, 2002.

Bates, T. S., Quinn, P. K., Covert, D. S., Coffman, D. J., Johnson, J. E., and Wiedensohler, A.: Aerosol physical properties and processes in the lower marine boundary layer: A comparison of shipboard sub-micron data from ACE-1 and ACE-2, Tellus, Ser. B, 52, 258-272, 2000.

Blomquist, B., Huebert, B. J., Fairall, C. W., and Faloona, I. C.: Determining the sea-air flux of dimethylsulfide by eddy correlation using mass spectrometry, Atmos. Meas. Tech. Discuss., 2, 19732025, 209,

http://www.atmos-meas-tech-discuss.net/2/1973/209/.

Blomquist, B., Fairall, C. W., Huebert, B., Kieber D., and Westby, G.: DMS sea-air transfer velocity: Direct measurements by eddy covariance and parameterization based on the NOAA/COARE gas transfer model, Geophys. Res. Lett., 33(7), doi:10.1029/2006GL025735, 2006.

Berresheim, H., Plass-Dulmer, C., Elste, T., Mihalopoulos, N., and Rohrer, F.: $\mathrm{OH}$ in the coastal boundary layer of Crete during MINOS: Measurements and relationship with ozone photolysis, Atmos. Chem. Phys., 3, 639-649, 2003,

http://www.atmos-chem-phys.net/3/639/2003/.

Bretherton, C. S. and Pincus, R.: Cloudiness and marine boundary layer dynamics in the ASTEX Lagrangian experiments. Part I:Synoptic setting and vertical structure, J. of Atmos. Sci., 52, 2707-2723, 1995.

Bretherton, C. S., Uttal, T., Fairall, C. W., Yuter, S. E., Weller, R. A., Baumgardner, D., Comstock, K., Wood, R., and Rag, G. B.: The EPIC 2001 stratocumulus study, B. Am. Meteor. Soc., 85(7), 967-977, 2004.

Caldwell, P., Bretherton, C. S., and Wood, R.: Mixed-Layer Budget Analysis of the Diurnal Cycle of Entrainment in Southeast Pacific Stratocumulus, J. Atmos. Sci., 62, No. 10, 3775-3791, 2005.

Charlson, R. J., Lovelock, J. E., Andreae, M. O., and Warren, S. G.: Oceanic phytoplankton, atmospheric sulfur, cloud albedo and climate, Nature, 326, 655-661, 1987.

Chen, G., Davis, D. D. Kasibhatla, P., Bandy, A. R., Thornton D. C., Huebert, B. J., Clarke, A. D., and Blomquist, B. W.: A study of DMS oxidation in the tropics: comparison of Christmas Island field observations of DMS, $\mathrm{SO}_{2}$, and DMSO with model simulations, J. Atmos. Chem., 37, 137-160, 2000.

Davis, D., Grodzinsky, G., Chen, G., Crawford, J., Eisele, F., Mauldin, L., Tanner, D., Cantrell, C., Brune, W., Tan, D., Faloona, I., Ridley, B., Montzka, D., Walega, J., Grahek, F., Sandholm, S., Sachse, G., Vay, S., Anderson, B., Avery, M., Heikes, B., Snow, J., O’Sullivan, D., Shetter, R., Lefer, B., Blake, D., Blake, N., Carroll, M., and Wang, Y.: Marine latitude/altitude $\mathrm{OH}$ distributions: Comparison of Pacific Ocean observations with models, J. Geophys. Res.-Atmos., 106, 32691-32707, 2001.

Davis, D., Chen, G., Bandy, A., Thornton, D., Eisele, F., Mauldin, L. Tanner, D. Lenschow, D., Fuelberg, H., Huebert, B., Heath, J., Clarke, A., and Blake, D.: Dimethylsulfide oxidation in the equatorial Pacific: comparison of model simulations with field observations for DMS, $\mathrm{SO}_{2}, \mathrm{H}_{2} \mathrm{SO}_{4}(\mathrm{~g}), \mathrm{MSA}(\mathrm{g}), \mathrm{MS}$, and NSS. Journal of Geophysical Research, Vol 104, NO. D5, 5765-5784, 1999.

Donahue, N. and Prinn, R.: Nonmethane hydrocarbon chemistry in the remote marine boundary layer, J. Geophys. Res., 95, 18387
$18411,1990$.

Edson, J. B., Hinton, A. A., Prada, K. E., Hare, J. E., and Fairall, C. W.: Direct covariance flux estimates from mobile platforms at sea, J. Atmos. Oceanic Technol., 15, 547-562, 1998.

Eisele, F. L. and Tanner, D. J.: Ion assisted tropospheric OH measurement, J. Geophys. Res., 96, 9295-9308, 1991.

Faloona, I., Lenschow, D., Campos, T., Stevens, B., van Zanten, M., Blomquist, B., Thornton, D., Bandy, A., and Gerber, H.: Observations of Entrainment in Eastern Pacific Marine Stratocumulus Using Three Conserved Scalars. J. Atmos. Sci., 62, 3268-3285, 2005.

Faloona, I., Tan, D., and Fuelberg, H.: Observations of $\mathrm{HO}_{\mathrm{x}}$ and its relationship with $\mathrm{NO}_{\mathrm{x}}$ in the upper troposphere during SONEX, J. Geophys. Res., 105, 3771-3784, 2000.

Hard, T. M., O’Brien, R. J., Chan, C. Y., and Mehrabzadeh, A. A.: Tropospheric free radical determination by FAGE, Environ. Sci. Technol., 18, 768-777, 1984.

Holland, F., Aschmutat, U., Heßling, M., Hofzumahaus, A., and Ehhalt, D. H.: Highly time resolved measurements of $\mathrm{OH}$ during POPCORN using laser-induced fluorescence spectroscopy, J. Atmos. Chem., 31, 205-225, 1998.

Huebert, B. J., Blomquist, B. W., Hare, J. E., Fairall, C. W., Johnson, J. E., and Bates, T. S.: Measurement of the sea-air DMS flux and transfer velocity using eddy correlation, Geophys. Res. Lett., 31, L23113, doi:10.1029/2004GL021567, 2004.

Hynes, A. J., Wine, P. H., and Semmes, D. H.: Kinetics and mechanisms of $\mathrm{OH}$ reactions with organic sulfides, J. Phys. Chem., 90, 4148-4156, 1986.

Kloster, S., Feichter, J., Maier-Reimer, E., Six, K. D., Stier, P., and Wetzel, P.: DMS cycle in the marine ocean-atmosphere system a global model study, Biogeosciences, 3(1), 29-51, 2006.

Levy H. I.: Normal Atmosphere: Large Radical and Formaldehyde Concentrations Predicted, Science, 173, 141-143, 1971.

Lilly, D. K.: Models of cloud-topped mixed layers under a strong inversion. Q. J. Roy. Meteor. Soc., 94, 292-309, 1968.

Lovelock, J. E., Maggs, R. J., and Rasmussen, R. A.: Atmospheric dimethyl sulphide and the natural sulphur cycle. Nature, 237, No. 5356, 452-453, 1972.

Mauldin, R. L., Eisele, F. L., Cantrell, C. A., Kosciuch, E., Ridley, B. A., Lefer, B., Tanner, D. J., Nowak, J. B., Chen, G., Wang, L., and Davis, D.: Measurements of $\mathrm{OH}$ aboard the NASA P3 during PEM-Tropics B, J. Geophys. Res., 106, 32657-32666, 2001.

Mount, G. H.: The measurement of tropospheric $\mathrm{OH}$ by long-path absorption, 1. Instrumentation, J. Geophys. Res., 97, 2427-2444, 1992.

Nowak, J. B., Davis, D. D., Chen, G., Eisele, F. L., Mauldin III, R. L., Tanner, D. J., Cantrell, C., Kosiuch, E., Bandy, A., Thorton, D., and Clarke, A.: Airborne observations of DMSO, DMS, and $\mathrm{OH}$ at marine tropical latitudes, Geophys. Res. Lett., 28(11), 2201-2204, 2001

Olson, J. R. Crawford, J. H., Davis, D. D., Chen, G., Avery, M. A., Barrick, J. D. W., Sachse, G. W., Vay, S. A., Sandholm, S. T., Tan, D., Brune, W. H., Faloona, I. C., Heikes, B. G., Shetter, R. E., Lefer, B. L., Singh, H. B., Talbot, R. W., and Blake, D. R.: Seasonal differences in the photochemistry of the South Pacific: A comparison of observations and model results from PEM-Tropics A and b, J. Geophys. Res., 106(D23), 3274932766, 2001. 
Platt, U. and Heintz, F.: Nitrate radicals in tropospheric chemistry, Isr. d. Chem., 34, 289-300, 1994.

Prinn, R., Cunnold, D., Simmonds, P., Alyea, F., Boldi, R., Crawford, A., Fraser, P., Gutzler, D., Hartley, D., Rosen, R., and Rasmussen, R.: Global Average Concentration and Trend for Hydroxyl Radicals Deduced From ALE/GAGE Trichloroethane (Methyl Chloroform) Data for 1978-1990, J. Geophys. Res., 97(D2), 2445-2461, 1992.

Prinn, R. G., Weiss, R. F., Miller, B. R., Huang, J., Alyea, F. N., Cunnold, D. M., Fraser, P. J., Hartley, D. E., and Simmonds, P. G.: Atmospheric trends and liftetime of $\mathrm{CH}_{3} \mathrm{CCl}_{3}$ and global $\mathrm{OH}$ concentrations, Science, 269, 187-192, 1995.

Read, K. A., Mahajan, A. S., Carpenter, L. J., Evans, M. J., Fari, B. V. E., Heard, D. E., Hopkins, J. R., Lee, J. D., Moller, S. J., Lewis, A. C., Mendes, L., McQuaid, J. B., Oetjen, H., SaizLopez, A., Pilling, M. J., and Plane, J. M. C.: Extensive halogenmediated ozone destruction over the tropical Atlantic Ocean, Nature, 453, 1232-1235, 2008.

Russell, L. M., Lenschow, D. H., Laursen, K. K., Krummel, B., Siems, S. T., Bandy, A. R. Thornton, D. C., and Bates, T. S.: Bidirectional mixing in an ACE 1 marine boundary layer overlain by a second turbulent layer, J. Geophys. Res., 103, 16411-16432, 1998.

Sander, S. P., Golden, D. M., Kurylo, M. J., Moortgat, G. K., Wine, P. H., Ravishankara, A. R., Kolb, C. E., Molina, M. J., FinlaysonPitts, B. J., Huie, R. E., and Orkin, V. L.: Chemical Kinetics and Photochemical Data for Use in Atmospheric Studies, Evaluation Number 15, Jet Propulsion Laboratory, Pasadena, CA, USA, online available at: http://jpldataeval.jpl.nasa.gov/, 2006.

Seinfeld, J. H. and Pandis, S. N.: Atmospheric chemistry and physics: from air pollution to climate change. $2^{\text {nd }}$ ed. WileyInterscience, Hoboken, New Jersey, USA, 2006.

Sciare J., Baboukas, E., Kanakidous, M., Krischke, U., Belviso, S., Bardouki, H., and Mihalopoulos, N.: Spatial and temporal variability of atmospheric sulfur-containing gases and particles during the Albatross campaign, J. Geophys. Res., 105, 1443314448, 2000.

Shon, Z. H, Davis, D., Chen, G., Grodzinsky, G., Bandy, A., Thornton, D., Sandholm, S., Bradshaw, J., Stickel, R., Kok, G., Mauldin, L., Tanner D., and Eisele, F.: Evaluation of the DMS Flux and its Conversion in $\mathrm{SO}_{2}$ Over the Southern Ocean, Atmos. Environ., 35, 159-172, 2001.
Shultz M. G., Jacob, D. J., Wang, Y., Logan, J. A., Atlas, E. L., Blake, D. R., Blake, N. J., Bradshaw, J. D., Fenn, M. A., Flocke, F., Gregory, G. L., Heikes, B. G., Sachse, G. W., Sandholm, S. T., Shetter, R. E., Singh, H. B., Talbot, R. W.: On the origin of tropospheric ozone and $\mathrm{NO}_{\mathrm{x}}$ over the tropical South Pacific, J. Geophys. Res. 104, 5829-5843, 1999.

Spivakowsky, C. M., Logan, A. J., Montzka, S. A., Balkanski, Y. J., Foreman-Fowler, M., Jones, D. B. A., Horowitz, L. W., Fusco, A. C., Brenninkmeijer, C. A. M., Prather, M. J., Wofsy, S. C., McElroy, M. B.: Three dimensional climatological distribution of tropospheric $\mathrm{OH}$ : Update and evaluation, J. Geophys. Res., 105, 8931-8980, 2000.

Stevens, B., Lenschow, D. H., Vali, G., Gerber, H., Bandy, A., Blomquist, B., Brenguier, J. L., Bretherton, C. S., Burnet, F., Campos, T., Chai, S., Faloona, I., Friesen, D., Haimov, S., Laursen, K., Lilly, D. K., Loehrer, S. M., Malinowski, S. P., Morley, B., Petters, M. D., Rogers, D. C., Russell, L., SavicJovcic, V., Snider, J. R., Straub, D., Szumowski, M. J., Takagi, H., Thornton, D. C., Tschudi, M., Twohy, C., Wetzel, M., and van Zanten, M. C.: Dynamics and Chemistry of Marine Stratocumulus - DYCOMS-II, 2003, B. Am. Meteorol. Soc., 84, 579-593, 2003.

Stickel, R. E., Zhao, Z., and Wine, P. H.: Branching ratios for hydrogen transfer in the reactions of OD radicals with $\mathrm{CH}_{3} \mathrm{SCH}_{3}$ and $\mathrm{CH}_{3} \mathrm{SC}_{2} \mathrm{H}_{5}$. Chem. Phys. Lett. 212, 312-318, 1993.

Wallington, T. J., Ellermann, T., and Nielsen, O. J.: Atmospheric chemistry of dimethylsulfide: UV spectra and self-reaction kinetics of $\mathrm{CH}_{3} \mathrm{SCH}_{2}$ and $\mathrm{CH}_{3} \mathrm{SCH}_{2} \mathrm{O}_{2}$ radicals and kinetics of the reactions $\mathrm{CH}_{3} \mathrm{SCH}_{2}+\mathrm{O}_{2} \mathrm{CH}_{3} \mathrm{SCH}_{2} \mathrm{O}_{2}$ and $\mathrm{CH}_{3} \mathrm{CH}_{2} \mathrm{O}_{2}+\mathrm{NO}$ $\rightarrow \mathrm{CH}_{3} \mathrm{SCH}_{2} \mathrm{O}_{2}+\mathrm{NO}_{2}$, J. Phys. Chem., 97, 8442-8449, 1993.

Wine, P. H., Kreutter, N. M., Gump, C. A., and Ravishankara, A. R.: Kinetics of $\mathrm{OH}$ reactions with the atmospheric sulfur compounds $\mathrm{H}_{2} \mathrm{~S}, \mathrm{CH}_{3} \mathrm{SH}, \mathrm{CH}_{3} \mathrm{SCH}_{3}, \mathrm{CH}_{3} \mathrm{SSCH}_{3}$, J. Phys. Chem., 85, 2660-2665, 1981.

Wood, R. and Bretherton, C. S.: Boundary Layer Depth, Entrainment, and Decoupling in the Cloud-Capped Subtropical and Tropical Marine Boundary Layer, J. Climate, 17, 3576-3588, 2004.

Yvon, S. A., Plane, J. M. C., Nien, C.-F., Cooper, D. J., and Saltzman, E. S.: The interaction between the nitrogen and sulfur cycles in the polluted marine boundary layer, J Geophys. Res., 101, 1379-1386, 1996. 